\title{
THE STATE POLICY IN THE FIELD OF PROVIDING FINANCIAL SECURITY AS A COMPONENT OF NATIONAL SECURITY: THE EXPERIENCE OF THE EUROPEAN UNION COUNTRIES
}

\author{
Yana Koval ${ }^{1}$, Nadiia Yurkiv ${ }^{2}$ \\ ${ }^{I}$ Ph.D. (Public Administration), Associate Professor, "KROK” University, Kyiv, Ukraine, e-mail: \\ koval_y.s@ukr.net,ORCID: https://orcid.org/0000-0001-6578-2996 \\ ${ }^{2}$ Doctor of Science (Economics), Professor, Adviser to the Directorate, National Institute for Strategic \\ Studies, Kyiv, Ukraine, e-mail: yurkiv_n@ukr.net,ORCID: https://orcid.org/0000-0003-4434-6698
}

\begin{abstract}
In the process of comprehensive development of the country, as an integral part of the world economy, the issue of national security, components of which are the economic, financial, military, information sectors, etc., is very acute. Current trends in globalization processes summarize the requirements and parameters of effective economic development of individual actors in the world economy. Only the positive dynamics of each component will ensure the positive dynamics of the world economy. Ensuring the sustainable development of any industry is impossible without the development and implementation of an independent strategy, which in today's economy is determined by the presence of an effective system of its financial security. The financial component characterizes itself as an internal functional component of its economic security, without exaggeration, is the main, because under market conditions is an important component of any economic system, determines the financial and economic condition of the entity, financial stability, solvency and structure dynamics sources of funding. Ukraine, as a state, is characterized by inexperience of a market economy, it requires the implementation of a number of measures to ensure public financial security. Each component of financial security, in addition to performing the relevant functions, is an integral part of the synergetic system designed to ensure the resilience of the national economy to internal and external negative influences and its effective functioning. The modern dynamics of social processes in Ukraine and the world necessitates the formation of an adequate, effective and economically justified system of protection of national interests and ensuring national (including economic and financial) security. The strategic goal of Ukraine's national security policy is to ensure state sovereignty and territorial integrity, national unity based on the democratic progress of society and the state, respect for human and civil rights and freedoms, creating conditions for dynamic economic growth, ensuring European social standards and welfare. The study analyzed the final act of the Conference on Security and Cooperation in Europe. The main positions of Ukraine in the ranking of individual components of the competitiveness index are highlighted. Characterized by the national economic interests of the European Union.
\end{abstract}

Keywords: economic security of the state, international experience, state policy, national economic interests, threats to economic security, public administration, national security.

JEL Classification: M10, M11, M21, H79, P35, E69

Formulas: 0; fig.: 0; tabl.: 0; bibl.: 13

Introduction. One of the priority tasks of the state is to ensure national security, including its economic component. In the structure of the latter, given the predominant role of finance in the national economy, a particularly important segment is financial security. The financial component of national economic security reflects the readiness of the financial system to timely and reliable financial support of the economic needs of public authorities and market institutions in sufficient amounts to maintain the required level of economic security. Neglecting the state of financial security of the state can lead to catastrophic consequences: the decline of the national economy, the bankruptcy of economic entities and, ultimately, the 
undermining of the life support system of the state with the subsequent loss of sovereignty.

Literature review. Methodological approaches to assessing the level of financial security of systems of different levels of complexity and hierarchy are devoted to the works of Baranovsky O., Ermolenko M., Kulpinsky S., Gordienko S., Kalacha G., Kozak L., Sukhorukova A, Shlemko V., Kovalenko O., Yermolenko M., Vlasyuk O., Ventskovsky D. and others. Their works investigate the main factors of financial security of the state and offer approaches to its assessment. At the same time, a much smaller number of scientific papers are devoted to the issue of financial security of the state as a component of national security.

Aims. The purpose of the study is to analyze the world experience of state policy in the field of financial security as a component of national security.

Methods. To solve this goal, the following research methods were used: observation and generalization; ordering of all basic elements; method of scientific generalization, which made it possible to formulate conclusions.

Results. Financial security is achieved through a prudent financial policy in accordance with duly accepted doctrines, concepts, strategies and programs in the political, economic, social, informational and, in fact, financial spheres. Under financial security we understand such a dynamic state of financial relations, which would create favorable conditions and necessary resources for expanded reproduction, economic growth and living standards, improving the national financial system to successfully combat internal and external factors destabilizing the financial situation in the country.

Without ensuring financial security, it is almost impossible to solve any of the tasks facing Ukraine. The urgency of financial security is determined by the need to form internal immunity and external protection from the destabilizing effects of competitiveness in world markets and the stability of the financial situation.

Discussion. The financial security strategy should be focused on the development and consistent implementation of measures to consolidate and develop positive processes and overcome negative trends in the field of financial relations. At the same time, the immediate goals of this strategy and mechanisms for their implementation should be defined.

The main condition for the development of the state in market conditions, on an innovative basis is the appropriate level of financial security, the criterion of which is financial security. The essence of the economic security of the state is balance and resistance to the negative impact of any threats, the ability to ensure sustainable and effective development of the state.

Financial security is a state of the financial sphere of the state, which is characterized by efficiency and balance, guarantees the stability of the financial system to the influence of internal and external negative factors, as well as enables stable economic growth and synergistic development of the country.

At the current stage of development of international economic relations, when Ukraine has chosen a strategy to ensure the economic security of the country in the context of identifying it as a European state, it is necessary to intensify its 
cooperation with European countries and develop a national economy strategy that meets European standards. Thus, the main task of the power structures of our state should be to develop effective directions of economic reform in the context of establishing Ukraine as an influential European state.

European financial security is understood as the stability of the conditions of economic development adopted for the international community or for an individual country. Of interest is the Final Act of the Conference on Security and Cooperation in Europe, where the section "Economic and Commercial Information" states that economic information should provide a full and relevant analysis of markets, facilitate the development of both short-term and long-term forecasts and include:

- statistics on production, national income, budget, level of consumption and productivity;

- statistics on foreign trade;

- laws and regulations relating to foreign trade;

- information used for economic forecasting to promote trade [1].

In conditions of financial and economic instability and military aggression in Ukraine, there are significant obstacles to the realization of economic interests in the implementation of the above European standards. Consider and analyze the main threats to external and internal financial and economic security of Ukraine at the present stage of its economic development and political course.

In the context of the reference to the socio-economic cohesion of the EU member states, the Lisbon Strategy plays an important role. According to the abovementioned document, the main priorities in strengthening the economic security of EU member states and the European continent as a whole should be: the principle of joint programming used in international cooperation projects, improving innovation participation to increase the competitiveness of economic regions in general, rural development and reference to territorial unity through the extensive development of a large part of the EU's regions.

In the context of the study of the problem of economic security at the global level, it is advisable to consider the methodology proposed by the UN Commission on Development Programs to analyze the economic security of the state. According to this methodology, the level of national security is determined by three factors: the level of the economy, the level of education and human rights.

The level of economic development is measured in GDP per capita, the level of education - the number of years during which a person studies in a given society, human rights are characterized by a special index, which is calculated according to a special approved Methodology [2].

It is clear that the decline in the above indicators over a period of study is a signal to the governments of all countries to take appropriate action. The level of GDP per capita is one of the main indicators of economic security of the state.

According to the methodology of the World Economic Forum, the country's GDP per capita should be classified into 3 categories:

- Countries with resource-oriented economies (GDP per capita less than 2000 thousand US dollars); 
- Countries with efficient-oriented economies (GDP per capita in the range of 3000-9000 thousand US dollars);

- Countries with socially-oriented and innovative economies (with a GDP per capita of more than 17,000 thousand US dollars).

After analyzing the position of Ukraine, it was found that it belongs to the group of countries in transition from resource-oriented to efficient-oriented economy, despite the growth rate of this indicator.

Regarding the indicators that characterize the average duration of training, it can be stated that, despite all the difficulties of political and economic nature, Ukraine manages to maintain competitive advantages not only in this indicator, but also in the level of education, quality of educational services and quality of natural and mathematical knowledge etc. [3].

This method of assessing the level of economic security by the UN Commission has significant shortcomings, as it does not take into account such important indicators as demographic, foreign economic, investment, innovation components, which reduces and makes it virtually impossible to apply in Ukraine. It can only be used in the context of comparing key indicators in Ukraine with other highly developed countries of the EU and the world.

It should be noted that the system of indicators proposed at the legislative level in Ukraine, which characterizes macroeconomic security, takes into account such indicators as: unemployment rate, GDP per capita in Ukraine to the average in EU countries, unemployment rate, level "shadowing" of the economy, the propensity of the population to save, the consumer index prices, GDP growth rate, employment in the informal sector. This, in turn, takes into account the principle of representativeness, reliability and information accessibility.

The next stage of the study is the trends in the formation of European financial security, because in a global economy, the European Union is beginning to play a leading role in ensuring the stability, development, prosperity and security of the European continent [4].

In Germany, ensuring the financial security of the state is also equivalent to maintaining the stability of economic growth. The country's main national security provisions, including financial ones, are set out in an official directive from the Ministry of Defense, which states that the German government sees the process of ensuring financial security in support of social and economic progress, protection from economic blackmail, democratization in Europe and worldwide, ensuring freedom of trade, access to raw materials and markets within a just global economic and financial system.

As you know, without significant stocks of raw materials, Germany is one of the largest consumers of imported raw materials in the world. Moreover, its dependence on raw materials from other countries is not considered by the government as a threat to economic security at a time when access to natural resources is one of the key factors influencing the international field. The Law "On Supporting the Stability and Growth of the German Economy" is one of the key tools for ensuring economic security in the country [5]. 
According to the normative document, the state must ensure the implementation of such economic policy, which would, within the chosen model of market economy, promote simultaneous price stability, high employment and foreign economic and equilibrium at a constant rate of economic growth. However, in Germany, as in the vast majority of EU countries, the main emphasis in the process of ensuring economic security is not on their own capabilities, but on general European (within the EU) security.

For example, the above-mentioned directive of the German Ministry of Defense states that the problems of our world can best be resolved through international discussion and compromise, so German security policy focuses on international relations and national institutions.

In France, the main state document, which affects certain provisions of financial security, is the National Security Act of 1964. The concept of national financial security is considered by this law as the creation of favorable internal and external conditions to increase and develop national welfare and strengthen economic potential. .

Analysis of the experience in ensuring the financial security of Western European countries such as the Netherlands, Belgium, Denmark, Luxembourg, Switzerland, shows that their main strategic goal to protect national economic interests is to ensure sustainable economic growth and economic modernization depending on competition in the world market [6].

Taking into account the national definitions of "financial security" and definitions in the legal systems of the above countries, we can conclude that the financial security of the state is the main component of national security, which contributes to the protection of national interests in the economy, the main criterion of which is the country's economy to contain internal and external threats.

The experience of forming the financial security of the United States of America is noteworthy. The national interests of the United States are defined by the National Security Strategy, which is classified according to the level of importance for the country into three categories:

- vital interests; important interests and humanitarian and other interests. Economic interests are part of the first category of importance of US national interests, the provision of which is an unconditional priority of the national security policy of the United States, for the protection of which the US government must do everything possible, even through unilateral use of force. These include the economic well-being of society and the protection of vital public infrastructures, including energy, finance, public communications [7].

The main directions of US national security policy are determined by the National Security Strategy in three main areas: the formation of a secure international environment in America, ensuring an adequate response to threats and crises, proper preparedness of American society for unpredictable trends and future phenomena.

Virtually every area involves measures to address financial security issues. 
The national peculiarities of Japan, which determine the formation of its views on the conduct of national economic security policy, include, first of all, the homogeneity and secrecy of Japanese society.

There are two main trends in the evolution of Japan's national security concepts: the "creeping" globalization of Japan's role in the world and its gradual autonomy within the framework of an alliance with the United States. However, the more Japan sees itself as a global power, the less conservative and realistic aspects remain in its doctrine of national interests [8].

In Romania, the National Security Strategy was approved in 1999 at a meeting of the Supreme Council of State Security. This most important document for the country is aimed at ensuring democracy and stability in the development of the state, integration processes.

The main areas of financial security are: implementation of effective measures of macroeconomic stabilization, acceleration of structural reforms in the economy, creation of the private sector, attraction of foreign investments and support of small and medium business; harmonization of financial and economic legislation, financial, economic and customs policy with European legislation, requirements and directives of the European Union [9].

In the Czech Republic, the main officially recognized conceptual document on state national security policy is the Security Strategy of the Czech Republic, which identifies national interests, threats and dangers to national security and formulates long-term state intentions and government measures to ensure peaceful development and economic prosperity. The security strategy identifies six main areas of national security: civil, public, politico-military, economic, environmental, and organized crime.

The strategic goal of the state national security policy in Poland in accordance with the Security Strategy is to guarantee the independence and sovereignty, the territorial integrity of the state; creating conditions for stable social and economic development; preservation of national heritage and development of national dignity of Poles. Among the key threats to Poland's economic security, the document calls the economic instability of neighboring countries and its negative impact on the domestic economy; uncontrolled migration processes, which could harm the socioeconomic stability and financial and economic opportunities of Poland; Poland's significant external dependence on energy imports and non-diversification of these sources [10].

In June 2000, the Government of the Republic of Poland adopted a conceptual document on national security, the Security Strategy of the Republic of Poland. The strategic goal of the state national security policy in Poland, in accordance with the Security Strategy, is to guarantee the independence and sovereignty, the territorial integrity of the state; creating conditions for development; preservation of national heritage and development of national dignity of Poles.

The defining threats to the financial security of the Republic of Poland include threatening economic instability in neighboring countries and negative impact on the Polish economy, significant external dependence of the state on energy supplies from 
abroad, non-diversification of these sources; uncontrolled migration processes that can damage the socio-economic stability and financial and economic capabilities of the state.

Officially recognized political views on the protection of citizens, society and the state from the impact of external and internal threats to national security in the Republic of Bulgaria are enshrined in the 1998 National Security Concept.

The national economic interests of the Republic of Bulgaria are:

- improving the quality and standard of living of the population, the efficiency of social and medical services in the country;

- ensuring state sovereignty, economic independence;

- achieving financial stability, a high level of economic and social development;

- increasing the effectiveness of domestic and foreign economic policy [11].

Threats to the financial security of the Republic of Bulgaria are:

- significant economic and social differentiation of countries on the continent, which threatens regional socio-political and socio-economic stability and has unpredictable consequences;

- spread of international financial and economic crime, smuggling of goods;

- application of trade, economic and financial sanctions against neighboring states;

- social instability in the state, the crisis of the national economy; lower living standards; demographic crisis,

- migration processes [12].

Security policy in the UK is closely linked to defense policy, it is based on assessments of national interests and is implemented through their protection.

Under the national interests in the field of economy understand the economic interests of society as a whole, which have priority over other forms of public interest.

In the United Kingdom, threats to financial security are also divided into external and internal, according to the degree of importance and probability of occurrence, which allows to distribute efforts and prevent the most dangerous of them in terms of national economic security. In this area, the government has traditionally relied on private business for maximum support, and the country has a welldeveloped system of institutions that ensures effective interaction between parliament, government and big business in developing and implementing solutions related to national financial security [13].

It includes organizations such as the Confederation of British Industry, the Council for Trade with Eastern Europe and a number of more specialized organizations representing the interests of industrialists and entrepreneurs.

The concept of financial security is considered in Spain largely in the context of the economic security of the entire European Union. At the same time, an effective system of ensuring national interests in the economic sphere has been created. It is based on: flexible legal and regulatory framework; clear division of competence of ministries, departments and organizations in the implementation of regulations related to economic development; the presence at each stage of development of a 
legally approved program of economic priorities, which in principle should exclude the possibility of targeted privileges; availability of special state control services.

In the system of ensuring economic prosperity and sustainable development of the country an important place is occupied by the definition of priority sectors of national industry; regulation of the procedure of investment stimulation; currency control; carefully developed legislation on joint-stock companies.

The policy of financial security of the Czech Republic, Poland, Slovakia and the Baltic States is based on the convergence of national interests with European interests, as well as political, economic and institutional transformation in accordance with Western European standards. In the early 1990s, these countries chose a similar model of financial security, which included: an assessment of the geopolitical situation in the region; definition of vector and development strategy; construction and implementation of a model of behavior, including in the field of economics, in accordance with the dominant trends of regional and global evolutionary process; the ratio of basic quantitative indicators of development with world and regional standards; correction of the course of economic reforms.

Conclusion. Given the above, it should be noted that the financial security system involves the separation and systematization of certain problems in national security, creating a strategy to overcome them through the implementation and implementation of effective mechanisms to counteract external and internal negative factors in the existing financial, economic and political system. The methodology for assessing the state of financial security is based on the analysis of indicators of financial and economic development of the state, the national regulatory framework on this issue, as well as the identification of negative trends in the overall characteristics.

In addition, the analyzed approaches to financial security of the European Union suggest that this level of security is quite high and depends on various factors. If Ukraine seeks to preserve the domestic market and an independent economic future during EU integration, it must go a long way in overcoming the economic crisis. To do this, it is important to understand the concept of the essence of financial security and clear and coordinated actions of authorized state bodies and structures to bring the level of financial security of Ukraine to the European level.

Author contributions. The authors contributed equally.

Disclosure statement. The authors do not have any conflict of interest.

\section{References:}

1. Bukovynskyi, S.A. (2012), "Financial crisis in Ukraine: it is necessary to use the economy and move from a larger economy", Finansy Ukrainy, №11, pp. 10-30.

2. Marhasova, V.H. (2011), "Foreign experience in ensuring the economic security of the region", Naukovyi visnyk ChDIEU, №1(9), pp. 53-61.

3. Chekhovych, H.T. (2013), "Methodical approaches to assessing the economic security of countries and regions", Efektyvna ekonomika, №5, retrieved from: http://www.economy.nayka.com.ua/?op=1\&z=2437.

4. Pilko, A.D. (2014), Evoliutsiia ta perspektyvni napriamy rozvytku bezpekoznavstva [Evolution and perspective directions of security science development], FOP "Drobiazko S. I.", Dnipropetrovsk, $166 \mathrm{p}$.

5. Kyrychenko, O.A. and Kudria, I.V. (2013), "Improving the management of financial security of enterprises in the financial crisis", Investytsii: praktyka ta dosvid, №10, pp. 22-26. 
6. Mihus, I.P. Andrienko, V.M. and Koval, Y.S. (2017), "International experience in shaping state policy in the field of financial security as a component of national security", Demokratychne vriaduvannia, №20, retrieved from: http://www.lvivacademy.com/vidavnitstvo_1/visnyk20/index.html.

7. Dolhopalova, M.M. (2010), "Some aspects of the process of ensuring the economic security of the state", Visnyk Zaporizkoho yurydychnoho iniversytetu, №3, pp. 110-115.

8. Akimova, L.N. and Lysachok, A.V. (2018), "State regulation of the financial services market in Ukraine", Public management, №1(11), pp. 29-45.

9. Koval, Ya. Mihus, I. Haman, P. and Andriyenko, M. (2019), "The state of economic security of Ukrainian banking institutions and the effect of economic reforms on formation of anti-crisis measures", Financial credit activity: problems of theory and practice, №2(29), pp. 32-43.

10.Maistro, S.V. (2015), "Directions for improving the mechanism of state management of financial and economic security of Ukraine in modern conditions", Aktualni problemy derzhavnoho upravlinnia, №1, pp. 95-101.

11.Malinovska, O.Ya. (2006), "Problems of state regulation of business development in Ukraine", Rehionalna ekonomika, №1, pp. 200-205.

12.Akimova, L.N.(2018), "Role and place of economic security in the system of state regulation providing for national security of Ukraine", Public management, № 2(12), pp. 15-27.

13.Tkach, A.A. (2012), "Institutionalization of global economic development", Biuleten Mizhnarodnoho Nobelivskoho ekonomichnoho forumu, №1(5), pp. 398-403. 